Nowoczesne Systemy Zarządzania

Zeszyt 13 (2018), nr 1 (styczeń-marzec)

ISSN 1896-9380, s. 171-172

Modern Management Systems

Volume 13 (2018), No. 1 (January-March)

ISSN 1896-9380, pp. 171-172
Instytut Organizacji i Zarządzania

Wydział Cybernetyki

Wojskowa Akademia Techniczna

w Warszawie

Institute of Organization and Management

Faculty of Cybernetics

Military University of Technology

\title{
Przywództwo w dowodzeniu - wykład wygłoszony przez dr. Briana Bucklesa reprezentującego National Defence University w Stanach Zjednoczonych
}

\section{Celina Sołek-Borowska}

Wojskowa Akademia Techniczna w Warszawie

Wydział Cybernetyki

W dniach 7-8 grudnia 2017 roku podczas konferencji naukowej pt. Nowoczesne koncepcje i metody zarzadzania, zorganizowanej przez Zakład Inżynierii Zarządzania IOiZ WCY WAT, mieliśmy zaszczyt gościć dr. Briana Bucklesa reprezentującego National Defence University w Stanach Zjednoczonych AP.

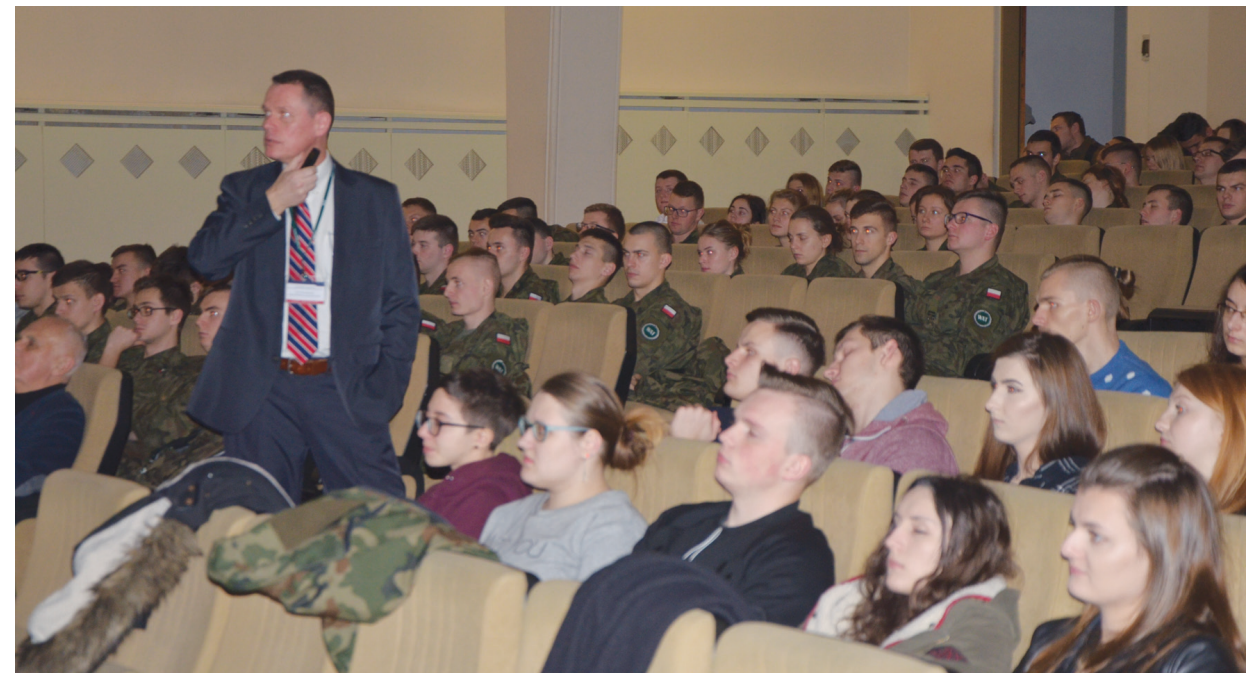

Fot. 1. Wykład dla podchorążych i studentów cywilnych przeprowadzony przez dr. Briana Bucklesa Fot. W. Gonciarski 
Dr Buckles przedstawił na konferencji referat pt. Improving management practices within defence acquisition (Poprawa praktyk zarzadczych $w$ przemyśle zbrojeniowym). Podczas wystąpienia podzielił się z uczestnikami doświadczeniem, które zdobył jako menedżer programowy odpowiedzialny za zakupy sprzętu bojowego dla korpusu marynarki wojennej Stanów Zjednoczonych, gdzie był odpowiedzialny za utrzymanie 900 LAV-ów.

Należy też zauważyć, że dr Brian Buckles posiada ponad 20-letnie doświadczenie operacyjne jako dowódca batalionu, zdobyte w trakcie misji na Bliskim Wschodzie.

Podchorążowie i studenci cywilni WAT mieli możliwość uczestniczyć w ponad godzinnym wykładzie zatytułowanym: Przywództwo w dowodzeniu, podczas którego dr Brian Buckles podzielił się doświadczeniem przywódczym z operacji Pustynna Burza (Desert Storm) oraz wojny w Zatoce Perskiej (Gulf War). W wykładzie wzięło udział około 150 studentów wojskowych i 30 studentów cywilnych studiujących na kierunkach zarządzanie oraz bezpieczeństwo wewnętrzne. 